\title{
Outpatient Management of Malignant Pleural Effusion Using a Tunneled Pleural Catheter: Preliminary Experience
}

Luis Seijo, Arantza Campo, Ana Belén Alcaide, María del Mar Lacunza, Ana Carmen Armendáriz, and Javier J. Zulueta

Departamento de Neumología, Clínica Universitaria, Universidad de Navarra, Pamplona, Navarra, Spain.

Inpatient management of malignant pleural effusion includes the placement of a conventional thoracostomy tube for drainage and talc slurry pleurodesis and/or a surgical approach consisting of video-assisted thoracoscopic talc insufflation. Both techniques require prolonged hospital stays of up to 1 week. Unfortunately, life expectancy in patients with this disease does not usually exceed 6 months, and so the primary aim of any palliative intervention intended to improve quality of life should be to avoid hospital admissions and to relieve pain as far as possible.

Of the few outpatient alternatives to hospital management the most frequently used is repeated thoracentesis. We describe the outpatient management of malignant pleural effusion by placement of a tunneled pleural catheter in a patient with stage IIIB lung adenocarcinoma. In our opinion, the use of this catheter offers a viable alternative to conventional therapy and is better tolerated.

Key words: Malignant pleural effusion. Tunneled catheter. Outpatient.
Manejo ambulatorio del derrame pleural maligno mediante colocación de un catéter de drenaje tunelizado. Experiencia preliminar

El manejo hospitalario del derrame pleural maligno incluye la colocación de un tubo de toracostomía convencional, drenaje y esclerosis mediante talcaje, y/o el abordaje quirúrgico mediante videotoracoscopia. Ambas técnicas requieren ingresos prolongados, de hasta una semana de duración. Lamentablemente, la esperanza de vida en pacientes con esta enfermedad no suele superar los 6 meses, motivo por el que toda intervención paliativa destinada a mejorar la calidad de vida debe tener como objetivo primordial el evitar, en la medida de lo posible, el ingreso hospitalario y aliviar el dolor.

Hay pocas alternativas ambulatorias al manejo hospitalario. De ellas, la toracocentesis de repetición es la más frecuentemente utilizada. Describimos el uso de un catéter tunelizado en el manejo ambulatorio del derrame pleural maligno de un paciente con adenocarcinoma de pulmón en estadio IIIB. Consideramos que este catéter ofrece una alternativa viable y mejor tolerada que el tratamiento convencional.

Palabras clave: Derrame pleural maligno. Catéter tunelizado. Manejo ambulatorio.

\section{Introduction}

Malignant pleural effusion is a much-feared complication of many cancers. In addition to carrying a poor prognosis, it is often accompanied by such symptoms as cough, chest pain, and shortness of breath that diminish the patient's quality of life. Bronchogenic cancer accounts for a third of malignant pleural effusions, followed in frequency by breast cancer; lymphoma; and, less commonly, malignant pleural mesothelioma and others. ${ }^{1-3}$ Mean survival in such patients does not usually exceed 6 months. ${ }^{4}$ The management of malignant pleural effusion, therefore,

Correspondence: Dr. L. Seijo

Departamento de Neumología. Clínica Universitaria de Navarra.

Avda. Pío XII, 36. 31008 Pamplona. Navarra. España.

E-mail:1mseijo@unav.es

Manuscript received February 7, 2006. Accepted for publication February 14, 2006. requires a palliative approach to relieve pain and allow symptoms to be controlled in the least aggressive and most effective way possible while shortening hospital stays.

Several techniques are available for the management of malignant pleural effusion. Repeated thoracentesis, although easy to perform and generally free of complications, is not the ideal approach, as in many cases the reaccumulation of fluid takes place within a very short time (as few as 4 days). ${ }^{5}$ For this reason, the usual approach is the placement of a conventional thoracostomy tube followed by talc slurry pleurodesis, or in some cases, the use of video-assisted thoracoscopic talc insufflation. Both therapeutic options, while very effective, are not free from complications and generally require hospitalization, which in some cases may exceed 10 days.

The development of several small caliber pleural catheters has opened the door to new strategies for the 

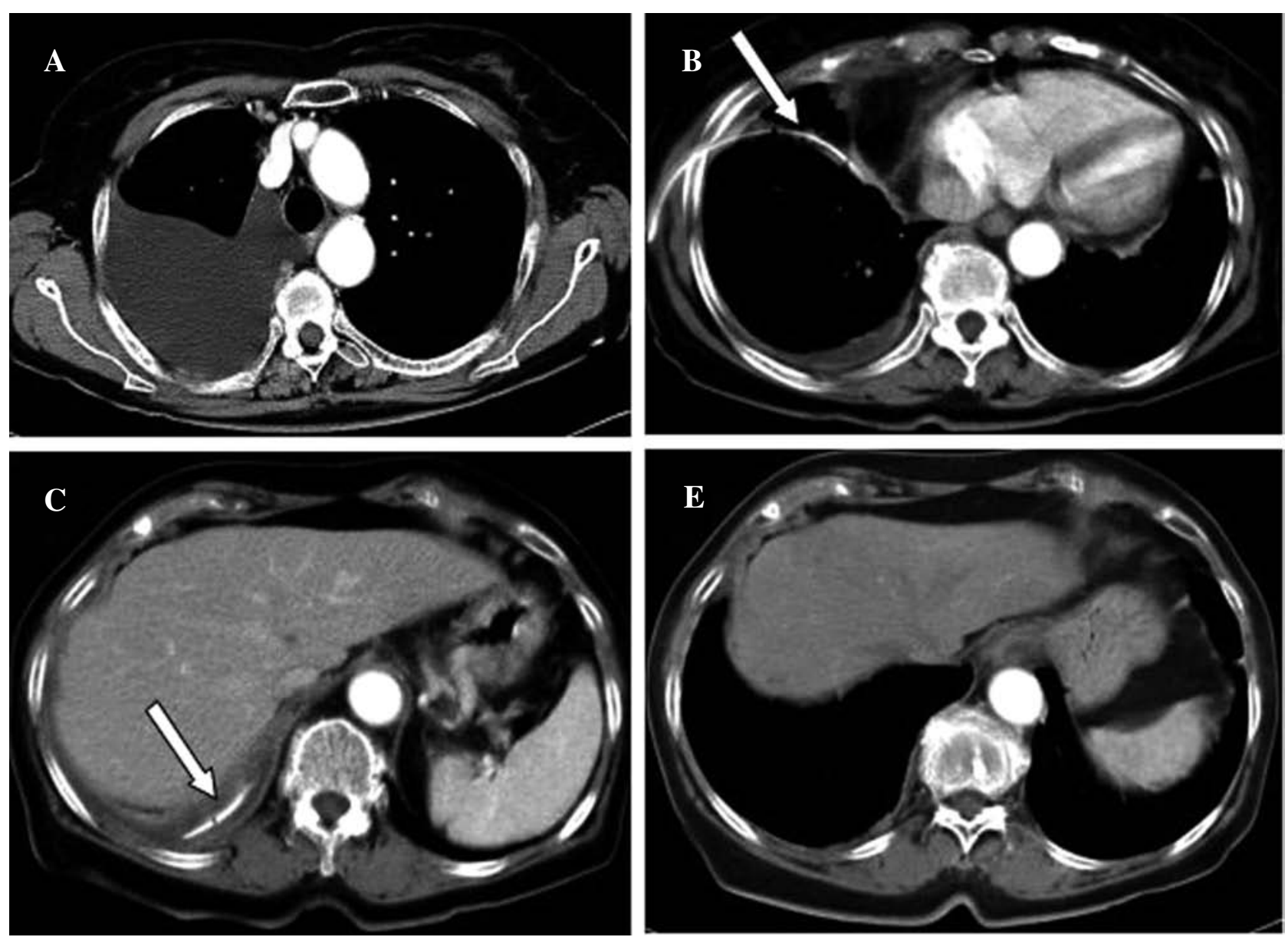

Figure 1. The computed tomography (CT) scan performed in April showed a large right-sided pleural effusion (A). Cytology confirmed the presence of tumor cells. The CT scan performed in May (B and C) showed a decrease in the amount of fluid. The arrows indicate the pleural drainage site. Two months after removal of the catheter $(D)$ it was confirmed that there was no reaccumulation of pleural fluid. Talc slurry pleurodesis was not necessary.

treatment of malignant pleural effusion with minimal associated morbidity, making outpatient management possible in some cases. ${ }^{6-9}$ Several studies have shown the palliative efficacy of such catheters, which are associated with lower costs, shorter hospital stays, and reduced pain. ${ }^{10-12}$

\section{Case Description}

We report the case of a 77-year old non-smoking woman diagnosed with stage IIIB lung adenocarcinoma with malignant pleural effusion. Although she initially responded to treatment with erlotinib, reaccumulation of pleural fluid was observed in February 2005 (Figure 1A). The effusion was associated with irritating dry cough and dyspnea that progressed until it appeared even on minimal effort. In the physical examination the most noteworthy findings were resting arterial oxygen saturation as measured by pulse oximetry of $95 \%$ and dullness to percussion at the base of the right lung with loss of normal vesicular sounds in a large part of this hemithorax. A chest x-ray taken in April showed clinically significant right pleural effusion and for that reason we chose to place a Pleurx pleural catheter (Denver Biomedical Inc, Golden, Colorado, USA) (Figures 1B and 1C). Catheter placement, performed under sedation (2.5 $\mathrm{mg}$ of midazolam) and local anesthesia after informed consent had been obtained, was uneventful. We drained $1100 \mathrm{~mL}$ of serosanguineous fluid and a family member was trained in how to use the device correctly under aseptic conditions in order to drain the pleural fluid at home every 2 to 3 days. The catheter was well tolerated by the patient, who hardly noticed its presence and did not experience dyspnea in the weeks following placement, although she did experience mild chest pain that responded to prescribed analgesic therapy. Once the quantity of fluid extracted had decreased to less than $50 \mathrm{~mL}$ on 3 consecutive occasions, we decided to remove the catheter 1 month after placement, after a computed tomography (CT) scan of the thorax confirmed the absence of effusion.

Another CT scan performed 2 months after the removal of the catheter (Figure 1D) showed only residual pleural thickening, with no reaccumulation of fluid. The patient died a few months later of causes unrelated to her respiratory disease, with no evidence of reaccumulation of fluid or dyspnea.

\section{Discussion}

The Pleurx catheter (Figure 2), like other similar ones, makes the reliable management of any malignant pleural effusion possible without hospitalization. The greatest advantage of this catheter is that it is tunneled 


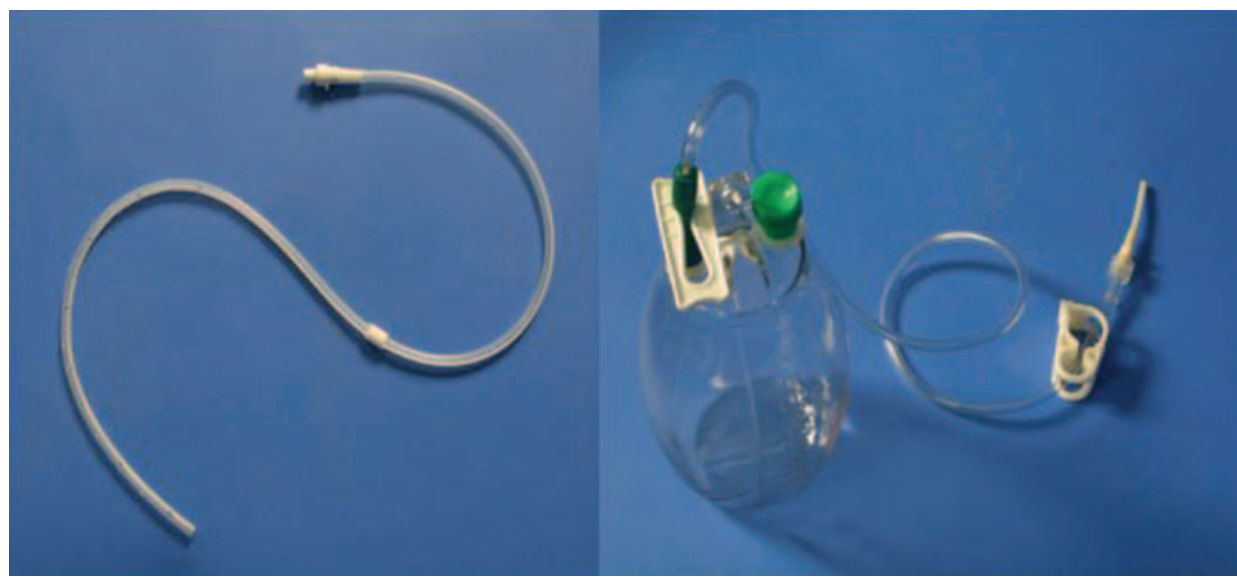

Figure 2. The Pleurx tunneled catheter (Denver Biomedical Inc, Golden, Colorado, USA) and a bottle for home drainage. and thus allows the patient to engage in normal activities with minimal risk of infection. The placement of this catheter requires no more than 20 minutes and allows pleural fluid to be drained at home. Various studies in the literature describe such adverse effects as the appearance of superficial skin infections (limited to the insertion site); mild chest pain; and, exceptionally, the tumor growth along the tunnel path. We describe our first clinical experience with the placement of a Pleurx catheter in Spain. As has been shown in other studies, the complications associated with the placement and handling of this catheter are minimal. Chemical sclerosis is unnecessary in up to $58 \%$ of cases, as sclerosis is achieved spontaneously in an average of 39 days. $^{13}$ The placement, handling, and later removal of the catheter are carried out on an outpatient basis. The Pleurx catheter has been shown to relieve the symptoms of dyspnea associated with malignant pleural effusion in all patients, regardless of whether or not sclerosis has been achieved. ${ }^{13}$ In addition to being better tolerated, the device is clearly associated with lower costs than conventional therapeutic options which require hospitalization ( $\$ 3392$ compared to $\$ 7830) .{ }^{14} \mathrm{~A}$ phase III clinical trial sponsored by the US National Cancer Institute (NCT00042770), designed to compare the efficacy of conventional thoracostomy with outpatient handling of malignant pleural effusion through the placement of tunneled catheters, is now underway. In that trial, the short- or medium-term impact of each therapeutic option on patients' quality of life, oxygenation, and control or eradication of the pleural effusion is being analyzed. ${ }^{13}$

\section{REFERENCES}

1. Sahn SA. Malignant pleural effusions. Clin Chest Med. 1985;6:113-25.

2. Hausheer FH, Yarbro JW. Diagnosis and management of malignant pleural effusion. Semin Oncol. 1985;12:54-75.

3. Lynch TJ Jr. Management of malignant pleural effusions. Chest. 1993;103:385S-9S.

4. Ruckdeschel JC. Management of malignant pleural effusions. Semen Oncol. 1995;22:58-63.

5. Anderson CB, Philipott GW, Ferguson TB. The treatment of malignant pleural effusions. Cancer. 1974;33:916-22.

6. Leff RS, Eisenberg B, Baisden CE, et al. Drainage of recurrent pleural effusion via an implanted port and intrapleural catheter. Ann Intern Med. 1986;104:208-9.

7. van Le L, Parker LA, de Mars LR, et al. Pleural effusions: outpatient management with pigtail catheter chest tubes. Gynecol Oncol. 1994;54:215-7.

8. Zeldin DC, Rodríguez RM. Management of refractory malignant pleural effusions with a chronic indwelling pleural catheter. Chest. 1991;100:87S

9. Grodzin CJ, Balk RA. Indwelling small pleural catheter needle thoracentesis in the management of large pleural effusions. Chest. 1997;111:981-8.

10. Putnam JB, Light RW, Rodríguez RM, et al. A randomized comparison of indwelling pleural catheter and doxycycline pleurodesis in the management of malignant pleural effusions. Cancer. 1999;86:1992-9.

11. Clementsen P, Evaid T, Grode G, et al. Treatment of malignant pleural effusion: pleurodesis using a small percutaneous catheter. A prospective randomized study. Respir Med. 1998;92:593-6.

12. Parker LA, Charnock GC, Delany DJ. Small bore catheter drainage and sclerotherapy for malignant pleural effusions. Cancer. 1989;64:1218-21.

13. Musani AI, Haas AR, Seijo LM, et al. Outpatient management of malignant pleural effusions with small-bore, tunneled pleural catheters. Respiration. 2004;71:559-66.

14. Putnam JB Jr, Walsh GL, Swisher SG, et al. Outpatient management of malignant pleural effusion by a chronic indwelling pleural catheter. Ann Thorac Surg. 2000;69:369-75. 